\section{EFL Students' Experiences in a Flipped Reading Comprehension Classroom}

1 Silvia Ramadhanty

2 Nina Puspitaloka

12 Universitas Singaperbangsa Karawang, Indonesia

\section{Ethical Lingua}

Vol. 7, No. 2, 2020

ISSN 2355-3448 (Print)

ISSN 2540-9190 (Online)

Corresponding Email

Silvia Ramadhanty

1610631060163@student.un

sika.ac.id

nina.puspitaloka@fkip.unsika. ac.id

Article's History

Submitted 26 June 2020

Revised 29 August 2020

Revised 17 September 2020

Accepted 23 September 2020

DOI

10.30605/25409190.188

Copyright $\odot 2020$

The Author(s)

This article is licensed under CC BY-NC-SA 4.0 License

\section{(c)) EY-NC-SA}




\section{EFL Students' Experiences in a Flipped Reading Comprehension Classroom}

In today's digital era, the application of learning models must be technology-based. One model of technology-based learning is the flipped classroom. The flipped classroom is an appropriate learning model to be applied in the digital era. Ansori \& Nafi' (2018) found that the use of the flipped classroom model provided positive responses for English teachers. Love, Hodge, Corritore, \& Ernst (2015) also stated that on the implementation of a flipped classroom, there is a positive effect where the strategy causes an active learning process in the classroom. Bishop \& Verleger (2013) in Ha, O’Reilly, Ng, Zhang, \& Serpa (2019) stated the "flipped classroom" is a teaching model in which the traditional behavioristic "lectures" take place outside the classroom that is before the in-class session via recorded video, while contact between the teacher and students is filled with more student-centred, active learning such as discussion and debate. The concept of the flipped classroom is that there are two sessions during learning. The concept of flipped classroom reflects the concept that teaching done now at home is traditional teaching in the classroom, and that traditional learning that is homework is now completed in class (Bergmann \& Sams, 2012 in Ansori \& Nafi', 2018). The first session is before a meeting where the teacher shares learning videos to all students. Moreover, the second session is a meeting where students are performing in group discussions. The research was conducted at the time of the Covid-19 pandemic. Therefore, it was not possible to conduct learning in the classroom at school. Researchers applied the online flipped classroom learning model. Although online learning, the concept of a flipped classroom is not eliminated because researchers used media to help the learning process. Researchers used WhatsApp and Zoom as media for learning. WhatsApp is used to share learning video links and performing group discussions, and Zoom is used to conduct face-toface meetings for questions and answers about material not understood by students.

Previous studies have focused on effectiveness, teacher's perspective, and challenges. Soliman (2016) conducted a study using a flipped classroom that aims to see the effectivity and challenges. Ansori \& Nafi' (2018) examined teachers' perspectives and challenges towards the flipped classroom. Vuong, Tan, \& Lee (2018) researched to see the challenges faced when students learn to use the flipped classroom model. This research was applied to first-grade students in senior high school while the previous research was applied to undergraduate students in the University. As in the research of Ha et al. (2019), Qader \& Arslan (2019), and Love et al. (2015) who implemented the flipped classroom at the University. Furthermore, previous studies, (Soliman, 2016; Ansori \& Nafi', 2018; Vuong, Tan, \& Lee, 2018; Ha et al., 2019; Qader \& Arslan, 2019; and Love et al., 2015), applied the flipped classroom model in the usual way, namely in the classroom at school, while this research used the flipped classroom in online learning. The used of WhatsApp and Zoom is needed fo online learning. Usually, the use of flipped classrooms is done by group discussions in class, but researchers conducted online group discussions using WhatsApp Group. Using technology such as those tools makes students could do the learning process on the same time just like the face-to-face meeting. Dharma, Asmarani, \& Dewi (2017) stated that online learning helps student saving time and costs. It also establishes a great teaching environment that will help teachers and students rather than traditional face-to-face classes. 
This research aimed to investigate EFL students' experiences during the application of the flipped classroom learning model. The researchers also investigate the challenges that appear in EFL students when applying the flipped classroom learning model.

\section{Method}

The research is conducted by using a qualitative approach and descriptive method. Hatch (2002) stated that explore human behavior in the context of a natural event is the purpose of qualitative research; this observation is used. In this research, the site or social setting is $X$ IPS 1 at one of the public senior high school in Karawang. Participants in this research are nine students chosen by an English teacher. According to Fraenkel et al. (2012) in Utari (2017), a sample between 1 and 20 is required for the participant of a qualitative study. Therefore, only a small number of samples was chosen from one class. The sample was nine students based on three low-level students, three middle-level students, and three high-level students. The school is chosen because first, the school has an A accreditation. Second, the school is easily reachable because it is not too far from where the researcher stayed. The tenth graders are chosen in agreement because ten graders are compatible with the materials that will be applied.

To collect the data, researchers used three research instruments. The research instruments used were observation guidelines, interview guidelines, and documentation. In collecting this data, the researcher took the steps; first, the observations are taken place, and then the interviews are conducted, and last, the documents were taken. The first step, observation, was carried out to see how students' experience during flipped classroom learning. Observation of participants aimed to see students 'engagement during classroom learning, to explore students' natural behavior (Hatch, 2002; in Azhar, 2013). In this step, the researcher observed the students' experiences by attending in Zoom meeting and following the discussion of students in WhatsApp group. It was done by the researcher to see directly for students' experiences. Interviews were conducted to determine students' experience and the challenges that appear in students during learning. Conducting interviews allows participants to discuss interpretations of the world they live in and to express considerations from their point of view of the situation (Cohen et al., 2013 in Azhar, 2013). In this research, the purpose of the author is to discover problems openly and students' feelings. In this step, the researchers called on WhatsApp videocall. The researchers asked students several question about the challenges they faced. The students are also asked about their feelings during the learning process. Furthermore, documentation is carried out to prove the authenticity of the data. The researchers collected some documentations from the process of observation, interviews, field notes, and file from the institution. The documentation is essential files from a record of events that have been occurred and carried out.

The data analysis used the theory of Huberman, Miles \& Saldana (2014). In this concept, there are three stages of data analysis. These stages are data reduction, data display, and conclusion. In the data reduction phase, the researcher focused on the teaching and learning process, which is conducted by the English teacher in the classroom. In the process of data reduction, there is the process of selecting, focusing, simplifying, abstracting, looking at the themes and patterns, and discarding unnecessary. The data is in the form of observation notes about the teacher's activity, the result of the interview, and lesson plan, and then the data is reduced to the narrative text. In data display, the data derived from activity observation, interview analysis. In this phase, the researchers describe the result briefly in a narrative. The data used in this phase was data taken by observation and interviews in this study. In 
conclusion, From the data display, it is analyzed further to derive the conclusions (Huberman, Miles \& Saldana, 2014). In conclusion, from the data display, it is analyzed further to derive the conclusions. The conclusion made during the research process is taken from analyzing the data display that has been made. This data is the result of observations and interviews.

\section{Results}

The result described the outcomes of research data that had been conducted by researchers. The data was used to answer and achieve the research objectives that have been made. The first research question was how the EFL students' experience during the application of the flipped classroom learning model and what were the challenges that appeared in students when applying the flipped classroom learning model.

\section{EFL students' experiences}

In applying flipped classroom online, researchers need media to conduct sessions before meeting and during meeting. This research was conducted using WhatsApp and Zoom as a medium during learning. Researchers choose WhatsApp and Zoom because students are already quite familiar with the application.

The research began by creating a WhatsApp group consisting of teachers and students. The group was used to share learning video links with students. To share Zoom meeting invitations, the researcher also used the WhatsApp group. For the discussion group process, it was used in a different WhatsApp group. The group discussion consisted of members of each group that had been determined by the teacher.

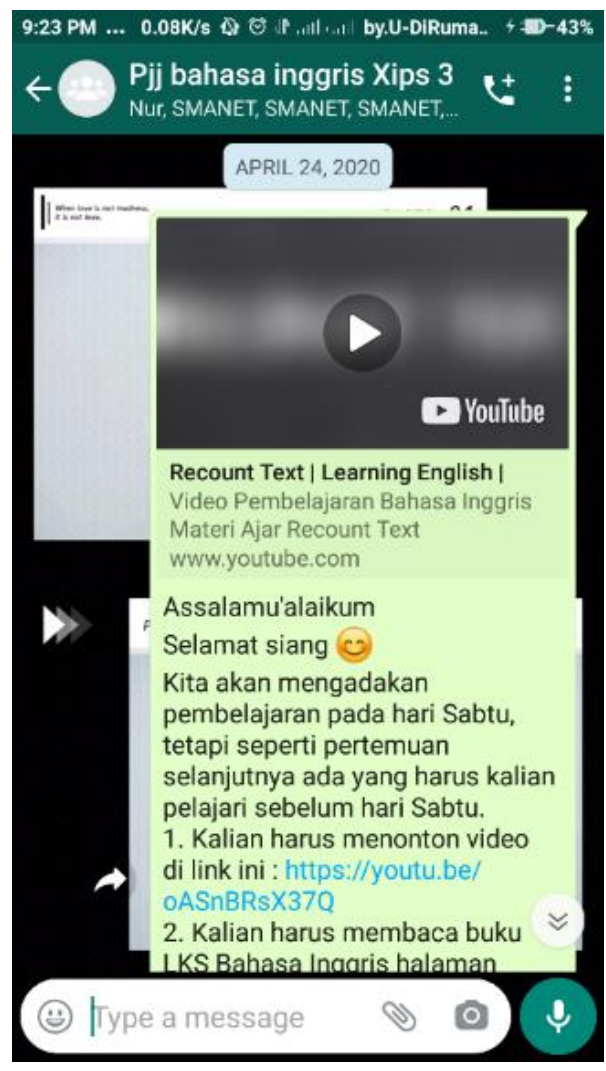

Figure 1. WhatsApp Group in Learning Recount Text though Flipped Classroom 


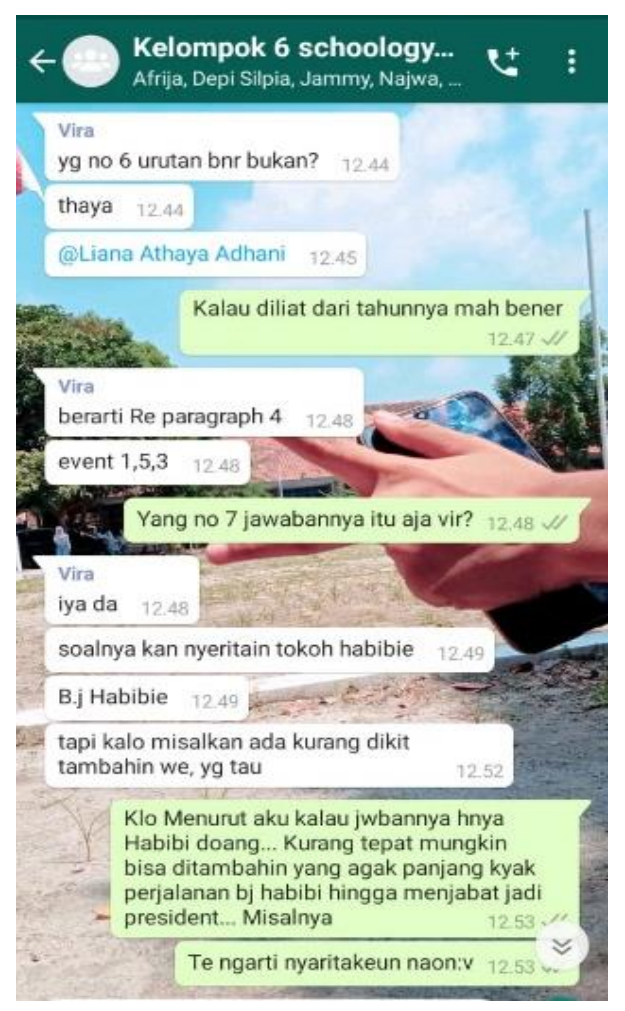

Figure 2. Students' Group Discussion

In the before meeting session, the teacher shared the learning video link to students. The teacher also reminded students and explained about zoom meeting. In this session, students listened and carried out the teacher's instructions well to watch the learning video so that they were ready and had an understanding of during meeting session.

On the during meeting session, the Zoom meeting was first held. Zoom meetings were divided into three sessions, and there were two groups in each session. Zoom meetings were held for ten minutes in each session. Zoom meeting is a part of during meeting session, where the session consists of zoom meting and discussion on WhatsApp group.

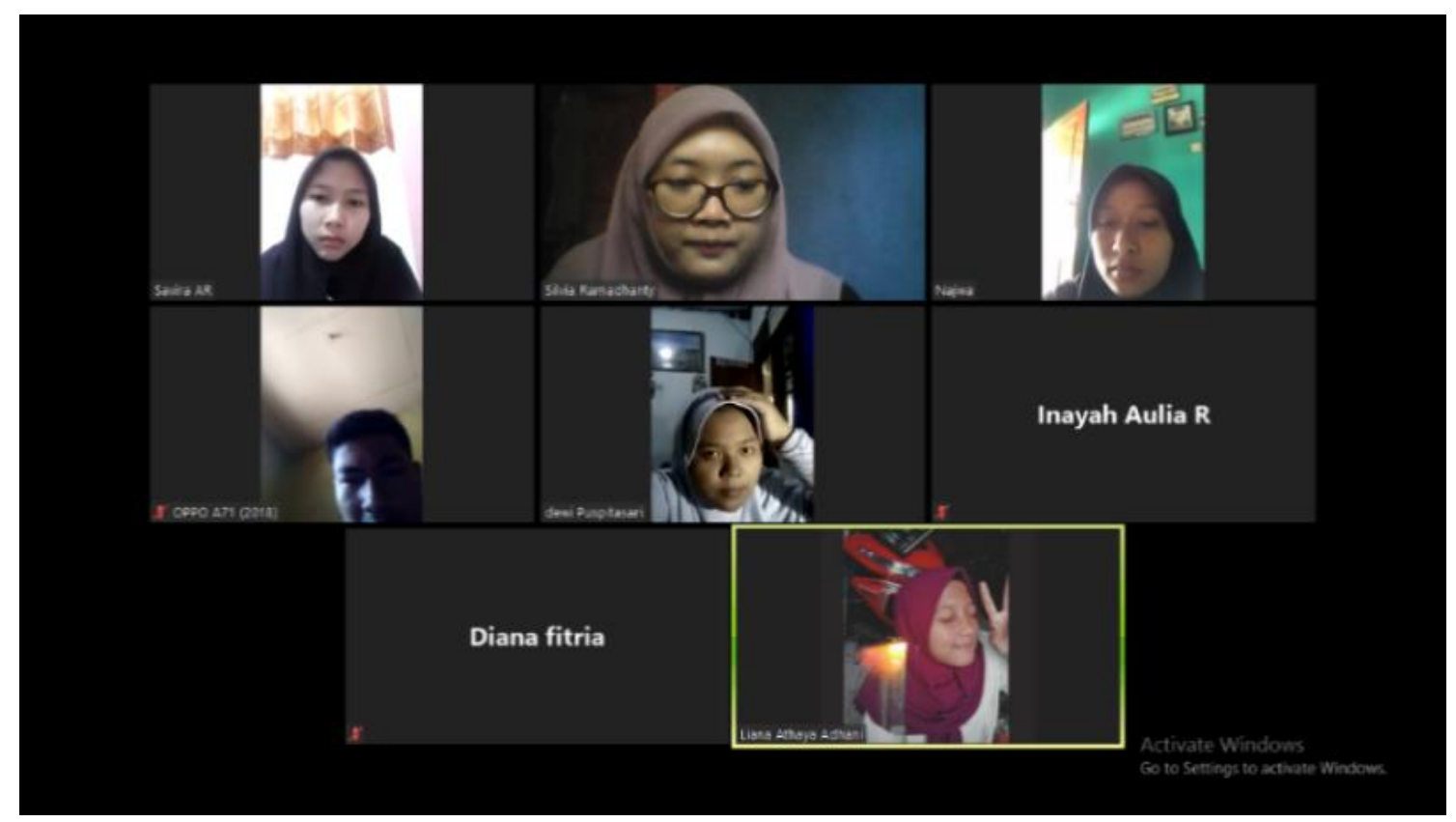

Figure 3. Zoom Meeting on During Meeting Session 
After conducting a Zoom meeting, the learning activities were continued with a discussion group on the WhatsApp group. First, the teacher shared files containing questions to be answered by each group. Students discussed to answer the questions shared by the teacher. After finishing the discussion, the students collected the answers. After the teacher checked each answer from the students, the teacher gave feedback to students. Group discussions went well, where students were active and enjoyed the learning process. If there were questions they do not understand, they asked their teacher and friends. They also appreciated the feedback that had been given by the teacher.

\section{Challenges that appear when applying the model}

At the last meeting, the teacher conducted interviews with students to find out what challenges they faced. There are several challenges faced by students, such as requiring internet access and an unstable internet connection.

\section{Internet access}

The implementation of online flipped classrooms required students to have internet access. During learning activities, students must have internet access continuously. It was stated by the student during the interview.

R2 Paling ada kendala pada koneksi internet ms, soalnya kan kalau belajar online harus ada koneksi terus...

(Obstacle on the internet connection, because if studying online you must always have an internet connection...)

\section{Internet connection}

Although students have internet access, some of them have difficulty getting a stable internet connection. It affected the Zoom meeting. Students found it difficult to access Zoom because of the unstable internet connection. They also said that the sound during the Zoom meeting was not clear if the internet connection was unstable. It was in accordance with the statement of students in the interview.

R3 Waktu di Zoom kadang suaranya kurang jelas soalnya koneksi internet tidak stabil...

(.... In Zoom sometimes the sound is unclear because of the unstable internet connection...)

\section{Discussion}

Based on the findings of the data, the findings of this research had been explained to how EFL students' experiences during the application of a flipped classroom learning model. The observation was carried out to see students' experiences and see challenges in students. Interviews were conducted to directly asked students about challenges and to find out how their experiences are during the implementation of flipped classrooms.

From the explanation of the interview and observations result, it could be concluded that the application of a flipped classroom provided a positive experience for them. During the learning process, students learned actively and enjoy learning activities. It also aligns with Mehring (2016), who found that finally, these programs allow students to discuss and communicate 
as they read the text online, creating an active learning environment outside of class that can aim at building critical thinking and helping students enjoy the reading process. The flipped classroom also had a positive impact on the relationship between students and teachers. Students tried to ask friends and teachers if they do not understand the material. It was aligned by Ceylaner \& Karakus (2018) that one of the most frequently cited themes to the factors that had positive effects on students' attitudes towards the English course was the interaction between friends and teachers.

Students enjoyed and excited learning by using video. Watching videos about learning material makes students like the flipped classroom model because it makes them understand the material deeper. The statement was stated by Ceylaner \& Karakus (2018), when students do not understand the topic, they had the chance to watch the videos again, which enabled an excellent opportunity to understand the topic and to succeed. Yavuz (2016) in Ceylaner \& Karakus (2018) also stated that investigated secondary school students' flipped classroom practices on academic success and student experiences and reported that students stated positive views about finding the opportunity to watch the videos wherever and whenever they wanted.

\section{Challenges}

From the explanation of the interview and observations result, it could be concluded that there are several obstacles during the activity. The main factors affected by learning are the internet connection because not all students who live in areas that have good internet access. As long as internet access is good, online studying will run well. An unstable internet connection also challenges students during the learning activity. This is in accordance with Singh \& Harun (2016) that in addition, regarding their mobile phones running slowly complained of by some students. Based on this problem, the researchers chose WhatsApp as a group discussion media. The use of WhatsApp was chosen because students are already accustomed to using it and are lighter to use. In another research, they were using WhatsApp as a medium, as stated by Ceylaner \& Karakus (2018) that during practice, the WhatsApp group was formed to share material. Previous studies have only used WhatsApp to share material. However, this research also uses WhatsApp for group discussion.

\section{Conclusion}

This research found that the application of a flipped classroom provided positive experiences for students. Flipped classroom makes the learning process more effective because there are before meeting and during meeting sessions. Before meeting sessions make the discussion activities at during meeting longer, his is because the explanation of learning material has been done at the before meeting. Therefore, students become more active and collaborate well with their friends. The use of videos makes them feel interested because they listen to the material comfortably and can be repeated. During group discussion activities, students enjoyed the learning process, being active during discussions, and being excited because watching videos made it easy for them to understand and could be repeated the explanations. These indicated that using flipped classroom provided positive feelings to the students. However, the use of online flipped classrooms creates several challenges faced by students. Challenges are students must have internet access while learning and the internet connection they have must be stable so that learning activities run well. To make a better learning process, English teachers are expected to make sure that all students have good internet access when applying flipped classrooms online. However, due to the limitations and 
weaknesses of the current study, more research is called for applying flipped classroom, not on online learning if the participants do not have good internet access. More researcher is suggested applying the flipped classroom directly face-to-face in the classroom.

\section{Acknowledgment}

The authors of the research would like to thank the headmaster at one of the public senior high school in Karawang who gave the opportunity and supports for completing this research. Thanks to the research adviser who had guided the authors to carry out the research.

\section{References}

Ansori, M., \& Nafi', N. N. (2018). English Teachers' Perceived Benefits and Challenges of Flipped Classroom Implementation. JEELS (Journal of English Education and Linguistics Studies), 5(2), 211-228. https://doi.org/10.30762/jeels.v5i2.820

Azhar, L. G., (2013), Students' Engagement in English Learning, [Undergraduate degree thesis, Universitas Pendidikan Indonesia].

Ceylaner, S. G., \& Karakus, F. (2018). Effects of the flipped classroom model on students' self-directed learning readiness and attitudes towards the English course. English Language Teaching, 11(9), 129-143. https://doi.org/10.5539/elt.v11n9p129

Dharma, H. R. C., Asmarani, D., \& Dewi, U. P. (2017). Basic Japanese Grammar and Conversation e-learning through Skype and Zoom Online Application. Procedia Computer Science, 116, 267-273. https://doi.org/10.1016/j.procs.2017.10.055

Ha, A. S., O'Reilly, J., Ng, J. Y. Y., Zhang, J. H., \& Serpa, S. (2019). Evaluating the flipped classroom approach in Asian higher education: Perspectives from students and teachers. Cogent Education, 6(1). https://doi.org/10.1080/2331186X.2019.1638147

Hatch, J. A. (2002). Doing qualitative research in education settings. Suny Press.

Huberman, A. M., Miles, M., \& Saldana, J. (2014). Qualitative data analysis: A methods sourcebook. SAGE publications.

Love, B., Hodge, A., Corritore, C., \& Ernst, D. C. (2015). Inquiry-Based Learning and the Flipped Classroom Model. PRIMUS, 25(8), 745-762. https://doi.org/10.1080/10511970.2015.1046005

Mehring, J. (2016). Present research on the flipped classroom and potential tools for the EFL classroom. Computers in the Schools, 33(1), 1-10.

Qader, R. O., \& Arslan, F. Y. (2019). The Effect of Flipped Classroom Instruction in Writing: A Case Study with Iraqi EFL Learners. Teaching English with Technology, 19(1), 3655. http://cejsh.icm.edu.pl/cejsh/element/bwmeta1.element.desklight-f3967ff3-1ee54fa3-ae98-ed2d080fe304

Singh, A. K. J., \& Harun, R. N. S. R. (2016). Students' Experiences and Challenges of Learning English Grammar Through Flipped Classroom and Gamification. Proceedings of EEIC, 1(2), 146-152. http://jurnal.unsyiah.ac.id/EEIC/article/view/15882

Soliman, N. A. (2016). Teaching English for Academic Purposes via the Flipped Learning Approach. Procedia - Social and Behavioral Sciences, 232, 122-129. https://doi.org/10.1016/j.sbspro.2016.10.036

Utari, M. (2017). An Error Analysis on the Use of Preposition in Narrative Composition Made by the Eleventh Grade Students of SMAN 1 Babat Toman Muba [Doctoral dissertation, UIN Raden Fatah Palembang].

Vuong, N. H. A., Tan, C. K., \& Lee, K. W. (2018). Students' Perceived Challenges of Attending a Flipped EFL Classroom in Viet Nam. Theory and Practice in Language Studies, 8(11), 1504. https://doi.org/10.17507/tpls.0811.16 